\begin{tabular}{|c|c|c|c|}
\hline$\Omega$ & $\square$ & $\equiv$ & (2) \\
\hline $\begin{array}{l}\text { Lauren Thomson', } \\
\text { Sangita Jain² }\end{array}$ & $\begin{array}{l}\text { 'Dept of Trauma and } \\
\text { Orthopaedic Surgery, } \\
\text { University Hospitals } \\
\text { Coventry and Warwickshire, } \\
\text { Coventry, UK } \\
\text { 'Dept of Microbiology, } \\
\text { Mid-Staffordshire Hospital, } \\
\text { Stafford, UK }\end{array}$ & $\begin{array}{l}\text { Lauren Thomson, Dept of } \\
\text { Trauma and Orthopaedic } \\
\text { Surgery, University } \\
\text { Hospital Coventry and } \\
\text { Warwickshire, Clifford } \\
\text { Bridge Road, Coventry, } \\
\text { CV2 2DX, UK }\end{array}$ & Lauren.thomsonı@nhs.net \\
\hline
\end{tabular}

\title{
An unusual case of breathlessness in a patient with chronic myeloid leukaemia
}

\section{Case Report}

\section{Case history}

A 67-year-old Caucasian male presented in January, 2013, with difficulty in breathing and pyrexia. This was following a course of antibiotics for a previous chest infection that had begun at the beginning of January and had not responded to therapy. His past medical history included chronic myeloid leukaemia, basal cell carcinoma of the throat treated in 2011, glaucoma and bilateral inguinal hernia repair (performed in 1989 and 2008). He was an ex-smoker of 21 years. His current medication was dasatinib (tyrosine kinase inhibitor) $100 \mu \mathrm{g} \cdot \mathrm{day}^{-1}$, amoxicillin/clavulanic acid $625 \mathrm{mg}$ three-times daily orally (changed to $1.2 \mathrm{~g}$ three-times daily intravenously) and bimatoprost $0.1 \mathrm{mg}$ eye drops.

On examination, the patient had a tachycardia of 108 beats $\cdot \mathrm{min}^{-1}$, oxygen saturation of $95 \%$ on $3 \mathrm{~L}$ of oxygen, a respiratory rate of 26 breaths $\mathrm{min}^{-1}$ and a blood pressure of 135/74 $\mathrm{mmHg}$. He had reduced breath sounds bilaterally in the lung bases, with dullness to percussion in the left lower zone. The rest of the examination was unremarkable.

\section{Task 1}

What investigations would be helpful at this point?
Conflict of interest

None declared.
CrossMark

$\leftarrow$ click for updates 


\section{Answer 1}

Simple blood tests: full blood count, C-reactive protein. Radiological: chest radiography. Microbiology: sputum and blood cultures.

The patient's white blood count was $22 \times 10^{9}$ cells $\cdot L^{-1}$, C-reactive protein was $345 \mathrm{mg} \cdot \mathrm{L}^{-1}$, red cell count was $10.5 \mathrm{~g} \cdot \mathrm{dL}^{-1}$ and platelets were $365 \times 10^{9}$ cells $\mathrm{L}^{-1}$. The liver function tests and urea and electrolytes were normal.

Chest radiography was performed (fig. 1).

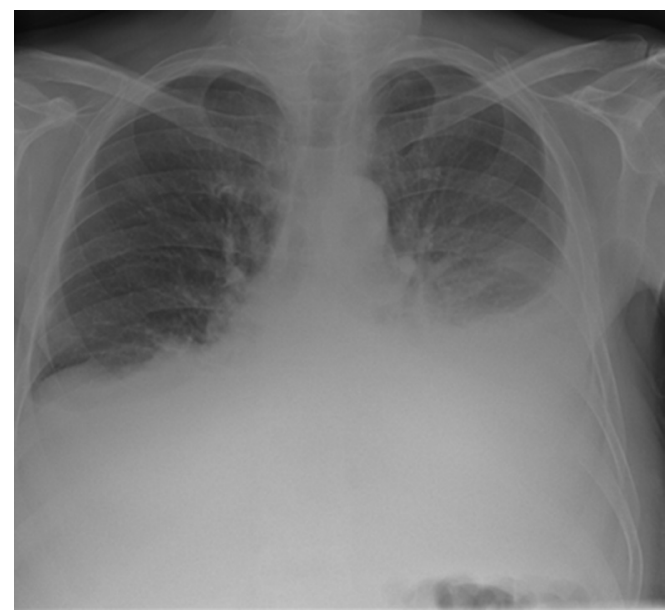

Figure 1

Plain film radiograph of the chest.

\section{Task 2}

Describe the radiographical findings. 


\section{Answer 2}

The radiograph shows bilateral pleural effusions, with the left being more extensive, large enough to require a chest drain. There is reduction in lung volume and loss of both costo-phrenic and cardio-phrenic angles. On ultrasound scanning, the effusion loculated.

The chest drain drained frank pus (total $750 \mathrm{mls}$ ); $500 \mathrm{~mL}$ of a "dirty brown" fluid was initially drained with a sample sent for cytology and microscopy.

\section{Task 3}

1. What is your differential diagnosis?

2. What bacteria are commonly associated with this presentation? 


\section{Answer 3}

1. Lower respiratory tract infection, pulmonary embolus, neutropenic sepsis, pleural effusion, myocardial infarction.

2. Streptococcus pneumoniae, Klebsiella pneumoniae, Haemophilus influenzae, Moraxella catarrhalis, Mycoplasma pneumoniae, Mycobacterium tuberculosis.

The pleural aspirate results were as follows: protein $51 \mathrm{~g} \cdot \mathrm{L}^{-1}$, glucose $<0.5 \mu \mathrm{mol} \cdot \mathrm{L}^{-1}$, albu$\min 28 \mathrm{~g} \cdot \mathrm{L}^{-1}, \mathrm{LDH} 2206 \mathrm{U} \cdot \mathrm{L}^{-1}$ and $\mathrm{pH} 6.56$. The pleural aspirate confirmed a growth of Salmonella typhinurium (also present in the blood culture), sensitive to amoxicillin/clavulanic acid, so the patient's treatment was continued to complete a 16-day course, of which, three doses were intravenous.

Additionally, a stool culture taken at the time grew Salmonella typhinurium.

This patient had had a similar episode in December 2012, during which he was admitted with left-sided chest pain, worse on cough and deep inspiration with pyrexia. He had a similar picture of dullness to percussion and reduced breath sounds within the left lower zone. A pleural tap was performed and fluid was sent for microscopy and cytology. A chest drain was inserted (into a loculated effusion) and $600 \mathrm{~mL}$ drained. On that occasion, no organism was grown. He was treated with piperacillin/tazobactam followed by amoxicillin/ clavulanic acid $625 \mathrm{mg}$ for 5 days, and his regular dasatinib was given.

\section{Discussion}

Salmonella spp. is a gram-negative, rod-shaped motile bacteria. It is member of the Enterobacteriaceae family with $S$. enteritides being the commonest isolate followed by $S$. typhinurium being the second-most common isolate [1]. It is an intracellular pathogen commonly associated with food poisoning. The bacterium has to be ingested in large quantities usually to produce an effect on the host, frequently gastroenteritis but also septicaemia [2].

Pleuropulmonary cases of Salmonella are rare, with fewer than 40 cases reported in the last century [2, 3]. A review of the literature shows that cases of Salmonella empyema are frequently associated with an underlying pathology, such as malignancy, an immunocompromised state, such as AIDS, or previous lung insult [4-6].

This patient had chronic myeloid leukaemia, basal cell carcinoma of the throat (non-metastasising) and had been on long term dasatinib. This could have pre-disposed him to susceptibility for pleuropulmonary Salmonella. Also the patient had a previous chest drain inserted into the lung for an effusion the previous month, meaning that there was an opportunity for a nidus of infection to develop [5], as Salmonella have developed various mechanisms for adapting host epithelium to enhance the likelihood of penetrance [7]. This is augmented by previous tissue damage and a weakened immune system.

There are a few theories which have been postulated as to why $S$. typhinurium, a predominantly gut-based organism can be found within the pleura [8]. As mentioned in other reported cases, many of the patients had a positive blood culture and it is therefore thought that spread was haematogenous from the gastrointestinal system [5]. There is also the argument that the infection can be due to an invasion from a local source. There are reported cases of Salmonella empyema, due to splenic or pancreatic abscesses [9, 10]. Finally, there is the possibility of a reticulo-endothelial spread, allowing for the dissemination of the Salmonella bacterium into the pleura [2].

The presentation of pleuropulmonary Salmonella infection was that of a typical pneumonia with an abrupt onset of difficulty in breathing, pyrexia and cough. It is important to recognise that pleuropulmonary diseases associated with Salmonella spp. are mostly associated with underlying pathologies, such as malignancy, HIV, chemotherapy, alcoholism and haemoglobinopathy $[3,11,12]$.

Once identified, the management of Salmonella empyema is similar to that of other pneumonia, i.e. drain the effusion (if possible) and treat with the appropriate course of antibiotics, in this particular case amoxicillin/clavulanic acid [13, 14].

\section{Conclusion}

Non-typhi Salmonella is a very rare but not unrecognised cause of empyema in the immunocompromised patient, and so should be excluded as a cause in patient with a difficult to treat exudative pleural effusion. 


\section{References}

1. Public Health England. Research and analysis. Salmonella infections (faecal specimens) England and Wales, laboratory reports (PHE salmonella data set). Available from https://www.gov.uk/government/ publications/salmonella-infections-faecal-specimens-in-england-and-wales-laboratory-reports-2014/ salmonella-infections-faecal-specimens-england-and-wales-laboratory-reports-phe-salmonella-data-set-december-2014 Date last updated: February 13, 2015. Date last accessed: May 2015.

2. Crum NF. Non-typhi Salmonella empyema: case report and review of the literature. Scand J Infect Dis 2005; 37: 852-857.

3. Kam J, Modi C, Abdul-Jawad S, et al. An unusual extra-intestinal manifestation of group $d$ salmonella infection. Am J Gastroenterol 2012; 2012: 4.

4. Cistulli PA, Barnes DJ, Young GA. Salmonella empyema in a patient with lymphoma. Aust N ZJ Med 1991; 21: 246-247.

5. Aguado JM, Obeso G, Cabanillas JJ, et al. Pleuropulmonary infections due to nontyphoid strains of Salmonella. Arch Intn Med 1990; 150: 54-56.

6. Kate $\mathrm{P}$, Osei K, Chiemchanya S, et al. Empyema due to Salmonella typhimurium with underlying alveolar cell carcinoma. South Med J 1984; 234-236.
7. Kalliomäki MA, Walker WA. Physiologic and pathologic interactions of bacteria with gastrointestinal epithelium. Gastroenterol Clin North Am 2005; 34: 383-399.

8. Hovette P, Camara P, Petrognani R et al. [Pleuropulmonary manifestations of salmonellosis.]. Med Trop 1998; 58: 403-407.

9. Prigogine T, Fastrez R, Glupczynski Y. Empyema due to Salmonella dublin. EurJ Respir Dis 1986; 68: 73-74.

10. Roguin A, Gavish I, Ben Ami H, et al. Pleural empyema with Salmonella mendoza following splenic abscesses in a patient with myelodysplastic syndrome. Isr Med Assoc J 1999; 1: 195-196.

11. Wolday D, Seyoum B. Pleural empyema due to Salmonella paratyphi in a patient with AIDS. Trop Med Int Health 1997; 2: 1140-1142.

12. Yang SY, Kwak HW, Song JH, et al. A case of empyema and mediastinitis by non-typhi Salmonella. Tuberc Respir Dis 2008; 2: 537-540.

13. Burney DP, Fisher RD, Schaffner W. Salmonella empyema: a review. South Med J 1977; 70: 375-377.

14. Rim MS, Park CM, Ko KH, et al. Pleural empyema due to Salmonella: a case report. Korean J Intern Med 2000; 15: 138-141.www.bbc.co.uk/news/uk-england-nottinghamshire-20021447 